\title{
A potential Green Anti-scaling and Corrosion Inhibitor for Mild Steel in Brine Solution
}

\author{
R.H. Khaled ${ }^{1}$, A.M. Abdel-Gaber ${ }^{2, *}$, H.T. Rahal ${ }^{1}$, R. Awad ${ }^{3}$ \\ ${ }^{1}$ Department of Chemistry, Faculty of Science, Beirut Arab University, Lebanon \\ ${ }^{2}$ Department of Chemistry, Faculty of Science Alexandria University, Ibrahimia, P.O. Box 426, \\ Alexandria 21321, EGYPT \\ ${ }^{3}$ Department of Physics, Faculty of Science, Beirut Arab University, Lebanon \\ *E-mail: ashrafmoustafa@yahoo.com
}

doi: $10.20964 / 2020.07 .54$

Received: 1 March 2020 / Accepted: 15 April 2020 / Published: 10 June 2020

\begin{abstract}
Mineral calcareous deposits are a current challenge in industrial water systems. The antiscalant properties of Prunus dulcis (Almond) leaf extract were tested using different chemical and electrochemical techniques. Fourier transform infrared spectroscopy (FTIR) was used to identify the functional groups of almond leaf extract. Static anti-scaling, conductivity, chronoamperometry, as well as optical photographic studies showed that almond leaf extract acts as a safe, ecofriendly antiscalant for steel in brine solution. Electrochemical impedance spectroscopy (EIS) technique and Potentiodynamic polarization curves measurements were used to test the inhibitive effect of Almond leaf extract on the corrosion of mild steel in brine solution. The results obtained showed that almond leaf extract acts as mixed type inhibitor. The corrosion inhibition increases by increasing the concentration of the extract up to a critical concentration. It is recommended to use $400 \mathrm{ppm}$ of almond leaf extract to impede the formation of scale deposits and provide an acceptable level of corrosion inhibition.
\end{abstract}

Keywords: Green Anti-Scalant, Almond Leaf, mild steel, Corrosion Inhibition, scale Deposition

\section{$\underline{\text { FULL TEXT }}$}

(C) 2020 The Authors. Published by ESG (www.electrochemsci.org). This article is an open access article distributed under the terms and conditions of the Creative Commons Attribution license (http://creativecommons.org/licenses/by/4.0/). 